\title{
Wizerunek Nikoli Tesli i jego wynalazków w grach cyfrowych
}

The image of Nikola Tesla and his inventions in digital games

\section{Jagoda Kościelniak}

Uniwersytet Gdański

jagoda.koscielniak@zoho.com | 0RCID: 0000-0002-1391-208X

\begin{abstract}
This article examines representations of the Serbian-American inventor Nikola Tesla in digital games, where he continuously gains popularity. Among twelve games in which he appears the following categories of his attributes were established and described: appearance, location, personality, role, abilities, inventions and relationships, which together create the image of a genius inventor.
\end{abstract}

Keywords: Nikola Tesla, scientist, Thomas Edison, physics, famous scientists, image 



\section{Wstęp}

Poruszająca historia Nikoli Tesli, amerykańskiego inżyniera serbskiego pochodzenia, stanowi źródło inspiracji dla różnych tekstów kultury. Jego postać można znaleźć w filmach, serialach, artykułach, grach planszowych, a także na koszulkach, kubkach czy ubrankach dla dzieci. Występuje też w grach cyfrowych, w których wykorzystywana jest na rozmaite sposoby - zgodne bądź niezgodne z historią. Pojawia się często jako tytułowy bohater, kiedy indziej jako ważna postać pomagająca protagoniście, a czasem choć nie pojawia się wcale, jego nazwisko i tak pada w grze przy nazwach różnych broni, przedmiotów czy technologii. W obliczu tak częstej i zróżnicowanej obecności genialnego wynalazcy zarówno w grach, jak i w kulturze popularnej warto przyjrzeć się bliżej temu fenomenowi. W pracy podjęta została zatem próba przedstawienia wizerunku genialnego wynalazcy w grach cyfrowych, w których się pojawia.

\section{Nikola Tesla: wizerunek, reprezentacja i metodologia badań}

Artykuł dotyczy wizerunku Nikoli Tesli - sposobu, w jaki jest on reprezentowany $w$ grach cyfrowych. Badania nad wizerunkiem i reprezentacją są szerokie, obejmują socjologię, językoznawstwo i literaturoznawstwo, a zarys ich historii możemy znaleźć w takich pracach jak The Work of Representation Stuarta Halla, gdzie autor znajduje elementy tych badań w teorii znaków Ferdynanda de Saussure'a, pracach Rolanda Barthes'a i Michaela Foucaulta (Hall, 1997, s.30, 36, 42). Problem reprezentacji pojawia się też w innych nurtach, jak np. w badaniach nad językowym obrazem świata (JOS), definiowanym przez jednego z jego głównych badaczy, Jerzego Bartmińskiego, jako „zawarta w języku, różnie zwerbalizowana interpretacja rzeczywistości, dająca się ująć w postaci zespołów sądów o świecie" (Bartmiński, 2007, s.12). Wizerunkiem zajmuje się również imagologia, „interesująca się obecnością, jak i strategią funkcjonowania obrazów w dyskursie kulturowym i literackim" (Boniecki, 2014, s. 150). 
W opisie wizerunku Tesli użyta została metodologia opracowania definicji kognitywnej zaproponowana przez Jerzego Bartmińskiego w badaniach nad językowo-kulturowym obrazem świata (Bartmiński, 2007, s. 45-51), natomiast zakres doboru danych wybrany został na podstawie wyodrębnionych przez Nikitę I. Tołstoja trzech kodów: werbalnego, przedmiotowego i akcjonalnego. Badacz sugeruje zastosowanie tej metody przy tekstach, które nie są tylko "ciągiem napisanych lub wypowiedzianych słów”. Jako przykład podaje obrzędy, zawierające też np. interakcje z przedmiotami i pod względem tekstowym wyrażone raczej semiotycznym językiem kultury niż w sposób werbalny (Tołstoj, 1992, s. 21-22).

\section{3. Życie Nikoli Tesli}

Nikola Tesla urodził się 10 lipca 1856 roku w serbskiej rodzinie, w austro-węgierskim miasteczku Smiljan, leżącym na obszarze dzisiejszej Chorwacji. Studiował inżynierię na austriackiej Politechnice w Grazu, gdzie badał zastosowania prądu zmiennego, po czym przeniósł się na Uniwersytet w Pradze. Wkrótce jednak porzucił studia. W 1882 roku zatrudnił się w Continental Edison Company w Paryżu, po czym przeniósł się do macierzystego oddziału firmy w Stanach Zjednoczonych. Współpraca z Edisonem jednak zakończyła się konfliktem wynikłym z niedotrzymania przez Amerykanina obietnic finansowych i odmowy podwyżki, o którą poprosił Tesla (Seifer, 1998, s. 8-39).

W 1886 roku założył z trzema innymi osobami własną firmę - Tesla Electric-Light \& Manufacturing - z której ku swojemu zaskoczeniu został usunięty i musiał zarabiać na życie, kopiąc doły. Jego los się odmienił, gdy otrzymał wsparcie od przedsiębiorcy George’a Westinghouse’a, z którym rozpoczął wieloletnią współpracę. Odnosili razem wielkie sukcesy, takie jak wybudowanie elektrowni wodnej czerpiącej energię z wodospadu Niagara czy oświetlenie Wystawy Kolumbijskiej w Chicago, raz po raz wykazując przewagę prądu zmiennego nad prądem stałym, promowanym przez Thomasa Edisona. Rywalizacja między Teslą i Westinghousem a Edisonem nazwana została „wojną prądów” (Seifer, 1998, s. 41-69, 100).

Tesla miał kilka laboratoriów w Nowym Jorku, z których jedno spłonęło w 1895 roku. Cztery lata później założył laboratorium w Colorado 
Springs, które dawało mu o wiele więcej swobody w eksperymentach (Seifer, 1998, s. 146 i 214-218).

W ostatnich latach życia zajmował się głównie ratowaniem chorych gołębi, odnosił mniej sukcesów i miał kłopoty finansowe. W dalszym ciągu jednak myślał o nowych wynalazkach - mówił chociażby o promieniu śmierci, który byłby w stanie zniszczyć całe armie z odległości 200 mil, czy o nieprzeniknionej tarczy między państwami. W 1943 roku zmarł w wieku 86 lat w swoim pokoju hotelowym (Seifer, 1998, s. 429-444).

\section{Wizerunek Nikoli Tesli w grach cyfrowych}

W pracy tej wzięto pod uwagę dwanaście gier cyfrowych, w których pojawia się postać Nikoli Tesli, pominięto zaś tytuły, w których zostaje tylko wspominany (czasami były to produkcje, w których jego nazwisko występuje w tytule, natomiast Tesla nie pojawia się w samej rozgrywce, jak np. Teslagrad). Są to wszystkie gry wydane do końca 2018 roku, które znaleziono poprzez wpisanie frazy „Nikola Tesla” lub „Tesla” na platformach Steam, GOG i Apple Store, a także na pierwszych trzydziestu stronach wyszukania fraz „Nikola Tesla video game”, „Nikola Tesla game” i „Nikola Tesla gra” w wyszukiwarce Google. Zebrane zostały dane werbalne (np. wypowiedzi postaci, notatki, opisy), przedmiotowe (np. lokacje, wygląd postaci, obiekty) i akcjonalne (np. mechanika gry) na temat Nikoli Tesli zawierające się w badanych grach. Dla przedstawienia sylwetki wynalazcy użyty został następujący dobór i układ faset': wygląd, miejsce pobytu, cechy, rola, umiejętności i wynalazki Nikoli Tesli, a także jego relacje z innymi postaciami, które razem zbierają się na językowo-kulturowy obraz wynalazcy w grach cyfrowych. Dane na temat jego wynalazków, zwłaszcza broni, ograniczone zostały do tych powtarzających się lub istotnych dla przedstawienia jego postaci (ważne fabularnie, wzorowane na rzeczywistych wynalazkach, świadczące o jego cechach charakteru). Przykładowo pominięte zostały liczne bronie pojawiające

1 „Faseta” jest terminem funkcjonującym w badaniach semantycznych „dla nazwania jednorodnych zespołów cech przypisywanych przedmiotowi w eksplikacji” (Bartmiński, 2007, s. 84). 
się w grze TVL czy trudne do zidentyfikowania wynalazki przedstawione w wizualnej części gier.

Tytuły gier używane są w formie skrótów, których rozwinięcie znajduje się w ludografii.

\subsection{Wygląd}

W badanych tytułach Nikola Tesla ma na sobie ubrania uchodzące za eleganckie, a mianowicie garnitur (wszystkie gry poza DV), kamizelkę (DV, TO), krawat (TVL, DV, SK, UWA, IH) i spodnie (wszystkie gry). Oprócz tego w TO można zobaczyć go w fartuchu roboczym, a w TGMT w piżamie. We wszystkich grach jest szczupły i ma wąsy (oprócz FGO, TO i VSA), określony też bywa jako przystojny (TBW, UWA, FGO), o przenikliwym spojrzeniu (UWA). W przypadku TO jest wyraźnie młodszy niż w pozostałych przedstawieniach - zwłaszcza w porównaniu z wizerunkiem w $I H$, w której to grze określony jest jako „starszy”. Natomiast w FGO jego wygląd odbiega od standardu wyznaczonego przez inne gry - Tesla nie ma tutaj zarostu, jest potężnie zbudowany, ma długie czarne włosy z niebieskimi pasemkami ${ }^{2}$.

Najbardziej wyróżniącym się tytułem jest VSA, gdzie, zgodnie $\mathrm{z}$ przyjętą w grze konwencją, Tesla jest zwierzęciem, a mianowicie antylopą.

\subsection{Miejsce pobytu}

Tesla często pojawia się w miejscach zgodnych z danymi biograficznymi na jego temat - w swoim laboratorium w Colorado Springs (DV, UWA, IH, TWM) i w Nowym Jorku (własne laboratorium w przypadku TBW, pokój hotelowy w $I H$, prawdopodobnie Shoreham ze względu na Wieżę Wardenclyffe $\mathrm{w} S K)$. W połowie $\mathrm{z}$ badanych produkcji znajduje się tam, gdzie toczy się akcja gry, czyli np. w fikcyjnym, austro-węgierskim miasteczku Sebenico (VSA), w Arkham ${ }^{3}$ (TVL), w Void (DV), na wyspie Hetam w Szkocji (IH), w Londynie (TO, FGO), na Marsie (UWA), a także w licznych lokacjach, do których zostaje przywołany do walki w SK i FGO.

2 W grze tej wiele postaci różni się drastycznie od swojego pierwowzoru (przykładowo Thomas Edison pod postacią lwa, czy Neron jako kobieta),

3 W IH też pojawia się sugestia, jakoby Tesla odwiedził to miejsce - ma kartę biblioteczną Uniwersytetu w Arkham. 
W dwóch grach miejsce jego pobytu jest niezidentyfikowane (ALT, TGMT). Ciekawym przypadkiem jest TBW, gdzie akcja w większości ma miejsce w alternatywnej rzeczywistości nazwanej Teslaverse.

W siedmiu grach Tesla posiada swoje własne laboratorium (DV, TBW, TWM, IH, UWA, TO, TGMT).

\subsection{Osobowość, cechy charakteru}

Główne cechy Tesli, które pojawiają się w analizowanych grach, związane są z jego geniuszem i pracą jako wynalazcy - mowa jest o jego wyjątkowym intelekcie (TBW, FGO, TWM), określony jest jako jeden z trzech największych umysłów XX wieku (TWM), w TO przy każdym spotkaniu chwalony jest przez głównego bohatera za inteligencję. Nazywa się go uosobieniem „postępu” i „przyszłości” (TVL, TGMT, FGO), ,współczesnym Prometeuszem” (FGO), ,dzieckiem burzy i światła” (TGMT). Ta jego strona szeroko przedstawiona jest w IH, gdzie setki pomysłów stale pojawia się w jego głowie, co sprawia, że postanawia ograniczyć dzienny odpoczynek do trzech godzin snu, aby więcej pracować. Przez sen rysuje też niezrozumiałe nawet dla siebie projekty. W UWA wspomina natomiast, że jest ciągle zapracowany, i ledwo ma czas na rozmowę $\mathrm{z}$ awatarem gracza. Zwykle te cechy nie są wyrażone werbalnie, ale warto zwrócić uwagę na to, że duża część gier przedstawia Teskę niemal wyłącznie w kontekście jego pracy naukowej (DV, UWA, TO, VSA, IH).

Inną cechą wynalazcy jest chęć do pomocy innym, zwykle też powiązana z życzliwością (VSA, DV, IH, UWA). Szczególnie w IH stara się za pomocą podróży w czasie pomóc ludziom naprawić ich błędy z przeszłości, wykazując się przy tym wewnętrznym imperatywem moralnym. Mimo błagań nie pomaga przyjaciółce ocalić jej męża ze względu na to, że skutkowałoby to śmiercią osób, które mąż, ginąc, uratował (z tego też powodu Tesla zostaje przez przyjaciółkę zamordowany). Anonimowo i bezinteresownie zapewnia również ludzkości darmową, nieograniczoną energię. Mimo powyższego jest to jedyna z przytaczanych gier, w której Tesla wykazuje się negatywnymi zachowaniami niepolegającymi wyłącznie na omówionej niżej konfliktowości. Pojawia się sugestia, że źle traktuje swoich służących, określony jest jako pozbawiony serca, łamie daną jednej z postaci obietnicę, że uwzględni ją w swoim testamencie, 
szantażuje Thomasa Edisona, grożąc, że ujawni światu, iż ten ukradł pomysł innemu wynalazcy. Jest też skłonny do kłamstwa i oszustwa.

Obserwując jego zachowanie w przytaczanych grach, można również określić go jako wykazującego się spokojem i opanowaniem, także w kryzysowych sytuacjach (TVL, DV, TBW, UWA, VSA, IH), z wyjątkiem TO, gdzie tonem głosu i mową ciała wykazuje pewną nerwowość, oraz TWM, gdzie reaguje emocjonalnie na przeciwności losu, np. pada załamany na kolana, gdy odkrywa, że jego laboratorium zostało zniszczone (choć reakcje Tesli nie są nigdy nieracjonalne).

Jego komiksowa biografia w TGMT przedstawia go jako marzyciela i miłośnika poezji, całe życie pracującego nad kontrolą ciała i umysłu. Sam siebie nazywa też tam „świadomym automatem”.

W VSA ze względu na niskie zarobki Tesla publikuje artykuły w erotycznym czasopiśmie dla fetyszystów cewek.

Skłonny jest do konfliktu polegającego zwykle na kąśliwych uwagach, głównie z Thomasem Edisonem (FGO, UWA, TO), i ze względu na charakter niektórych gier (np. tzw. bijatyk) - do walki z użyciem przemocy (TVL, TBW, SK, FGO, TWM).

\subsection{Rola}

W siedmiu grach Tesla jest postacią grywalną (TVL, TWM, TBW, SK, ALT, TGMT, FGO), z czego we wszystkich przypadkach oprócz SK i FGO jest też głównym bohaterem.

Najważniejszą rolę pełni w TBW, ALT, TGMT i TMW, gdyż fabuła tych gier jest w całości oparta na jego postaci i wątkach biograficznych z życia prawdziwego Nikoli Tesli.

Typową jego rolą jest też dostarczanie innym postaciom wynalazków, które stanowią rozwiązanie problemów fabularnych (VSA, TO, DV, UWA).

W czterech grach Tesla jest jednym z reprezentantów postaci historycznych (SK, VSA, UWA, FGO).

Ciekawy przypadek stanowi gra $I H$, gdzie oprócz jednego rozdziału wynalazca jest martwy, a fabuła opiera się na znalezieniu jego mordercy.

\subsection{Umiejętności}

We wszystkich przedstawionych tytułach Nikola Tesla jest wynalazcą powiązanym z elektrycznością. Własnoręcznie kontroluje pioruny (TVL, 
SK, FGO, TWM). Ze względu na charakter gier, w których występuje jako postać grywalna, jest często bardzo sprawny fizycznie - wysoko skacze (TBW, SK, TWM), posługuje się różnymi rodzajami broni (TVL, TBW, SK, TO), lata (ALT, TGMT). W TBW może wykonać podwójny skok, odbijając się drugi raz z samego powietrza, co narrator tłumaczy tym, że postać jest w stanie łamać prawa fizyki ze względu na samo bycie Teslą.

\subsection{Wynalazki}

Powtarzającymi się wynalazkami są cewka Tesli (TVL - jako Tesla Stick, DV, TBW, UWA, TO, TGMT, VSA, IH), nieskończona, darmowa energia elektryczna ( $\left.D V, V S A^{4}, I H, F G O\right)$, Wieża Wardenclyffe (TVL, TBW, SK), teleport (TVL, TBW, VSA), wehikuł czasu (IH, UWA), komunikator bezprzewodowy pod różnymi nazwami (TO, IH, TWM), promień śmierci (TVL, TBW, $S K)$. Istotnymi dla fabuły i mechaniki gry wynalazkami są jetpack (DV), komunikator między Marsem a Ziemią (UWA), ochronne pole elektromagnetyczne i polaryzacja elektronów organizmu w celu ochrony przed tym polem (VSA).

Oprócz cewki Tesli i Wieży Wardenclyffe rzadko pojawiają się wynalazki, które nie pełnią żadnej roli w fabule czy mechanice gry, takie jak kokon leczący zaparcia ${ }^{5}$ (VSA) czy mechaniczny Tesla grający w szachy (IH). W TGMT Nikola Tesla konstruuje robota, któremu nadaje imię swojego zmarłego brata - Dane.

Wynalazki określane są głównie pozytywnie - jako niesamowite (incredible) w VSA czy „mechaniczne cuda” w IH, a negatywnie przez przeciwników - jako niebezpieczne (dangerous) w TVL czy „śmieci” (piece of junk) w TBW.

W TBW Tesla jest autorem tysięcy wynalazków i ponad 800 patentów.

\subsection{Relacje}

\subsubsection{Relacje z gtównym bohaterem}

W grze DV w zamian za wypełnienie zadania Nikola Tesla pomaga głównemu bohaterowi, który początkowo jest wobec niego nieufny, podejrze-

4 W tej grze pod pojęciem „nieskończonej, darmowej energii” kryje się to, że Tesla po prostu kradnie prąd z elektrowni wodnej, którą zbudował dla cesarza Austro-Węgier.

5 Warto zauważyć, że choć w grze jest to przedstawione jako żart, Tesla rzeczywiście był autorem podobnego wynalazku (Seifer, 1998, s. 128). 
wając go o bycie faszystą (DV). W TO wynalazca przyjaźni się z głównym bohaterem i ratuje mu życie.

W UWA Tesla jest życzliwy i cierpliwy wobec głównego bohatera i nazywa go swoim przyjacielem, jednak jest stanowczy w momencie, gdy ten popełnia błędy.

Specyficzna sytuacja ma miejsce w grze $I H$, gdzie w dodatkowym zakończeniu Tesla komunikuje się bezpośrednio z postacią gracza. Nakłania ją - a właściwie zmusza, gdyż bez wykonania polecenia nie można zakończyć rozgrywki - do skoku z okna pokoju hotelowego wynalazcy w celu upozorowania jego śmierci (nierozpoznawalne po upadku ciało awatara ma zastąpić ciało Nikoli Tesli).

W pozostałych grach nie pojawia się główny bohater niebędący Teslą (TVL, TBW, SK, FGO, ALT, TGMT, TWM).

\subsubsection{Relacje z przeciwnikiem}

Zdecydowanie najczęściej jako rywal pojawia się Edison - występuje $\mathrm{w}$ tej roli aż w dziewięciu badanych grach (TBW, FGO, ALT, UWA, TO, TGMT, VSA, IH, TWM). Konflikt między wynalazcami widoczny jest już w wydanej w 1991 roku grze UWA - Edison mówi pogardliwie o Tesli, nazywając go „smarkaczem” (whippersnapper), „szalonym” (crazy) i cieszy się, gdy Tesla się myli. Sam Tesla z kolei nazywa Edisona "starym zrzędą” (old curmudgeon), jednak przyznaje, że jego rywal lepiej zna się na marsjańskiej maszynerii.

W grze TWM Edison próbuje zabić Teslę i zniszczyć świat z pomocą czołgów $\mathrm{i}$ innych maszyn, w końcu jednak Tesla pokonuje go, a diaboliczny Edison ginie. George Westinghouse proponuje wtedy zatuszowanie wszystkich tych wydarzeń i pozwolenie na to, aby ku pamięci Edisona zgodzić się na przypisanie mu autorstwa kilku wynalazków Tesli, co stanowi w grze wytłumaczenie dla rzeczywistej wersji historii. Konflikt ten stanowi też ważny wątek w grze IH, gdzie Edison i Tesla są porównani do Salieriego i Mozarta.

W większości przypadków produkcje zwracają uwagę na to, że Edison stworzył wynalazki mniej ważne niż Tesla. Oprócz tego Edison często jest oskarżany o kradzież pomysłów Tesli (TWM, TBW, IH), w jednej z gier określoną eufemistycznie „pożyczaniem” jego wynalazków $(\mathrm{TBW})$. 
Konflikt widoczny jest też w grze TO. W laboratorium Nikoli Tesli można znaleźć zaproszenie z fotografią Edisona, której wynalazca dorysował zarost i rogi. Wspomina też, że nie rozmawiają ze sobą, i nazywa Edisona „idiotą".

Zarówno w TBW, jak i w TWM jego laboratorium zostaje spalone przez Edisona. W tych samych grach adwersarz Tesli ginie na skutek konfliktu, przy czym w TBW trzykrotnie - jako zwykły Edison, Mecha-Edison i Zombie-Edison (inaczej Zedison). Oprócz tego w TBW jest silnie zasugerowane, jakoby Edison pełnił rolę narratora gry, który dezawuuje wynalazki Tesli, nazywając je „bezużytecznymi” (useless), „śmieciami” (piece ofjunk, piece of garbage), sugeruje, że atakujące świat zombie są skutkiem prądu zmiennego. Pyta też Teslę, czy zastanawia się, o ile łatwiej by mu wszystko szło, gdyby był Thomasem Edisonem (Do you ever wonder how easier it would have been if you were Thomas Edison?).

W TGMT Edison jest określony jako próbujący powstrzymać korzyści, które niesie światu prąd zmienny Tesli, ze względu na zyski finansowe (aczkolwiek myślenie głównie o pieniądzach pojawia się po obu stronach konfliktu). Nikola Tesla nazywa go też złym pracodawcą.

W FGO Tesla zostaje nazwany godnym rywalem Edisona. Ten nazywa imię Serba nieprzyjemnym, prosi też, aby nie mówić przy nim o Tesli.

Gra ALT zawiera walkę między dwoma wynalazcami jako jedyną fabułę gry - Tesla unika prądu stałego, którym atakuje go Edison.

Interesujący jest przypadek gry TVL, w której H. P. Lovecraft jest głównym przeciwnikiem Nikoli Tesli, usiłującym walczyć z postępem, który wprowadza wynalazca. Tu również laboratorium Tesli zostaje spalone, tym razem przez potwory z twórczości rzeczywistego Lovecrafta.

Inni przeciwnicy, zwłaszcza występujący w SK, FGO, TVL i TBW, nie są oparci na osobistych relacjach z Teslą.

\subsubsection{Relacje z innymi postaciami}

Mark Twain pojawia się dwukrotnie jako przyjaciel Tesli - jest narratorem gry TWM, w której nazywa Teslę swoim „drogim przyjacielem”, a ich wspólny portret wisi w laboratorium wynalazcy. Wspólne zdjęcie tej dwójki pojawia się też w grze IH, gdzie znaleźć można także fotografię Tesli z Albertem Einsteinem. W obu tytułach wspomniany jest George Westinghouse jako wspólnik biznesowy wynalazcy. 
W IH znaleźć można list Tesli do Elona Muska, w którym wyznacza go na kontynuatora swojego dziedzictwa. W DV mieszka wśród członków żyjącego w alternatywnym świecie plemienia i przyjaźni się z jego wodzem, a także bezinteresownie pomaga $\mathrm{w}$ walce $\mathrm{z}$ wrogimi kosmitami za pomocą swoich wynalazków. Współpracuje z Zakonem Rycerzy Okrągłego Stołu i rebeliantami w grze TO.

Trzy tytuły nawiązują też do rzeczywistej miłości Tesli do gołębi: w TBW jego postać posiada jednego ptaka, w TWM kolekcjonuje gołębie, a sterowany przez wynalazcę w TVL mech nazywa się "Gołąb Wojenny” (War Pigeon), tam również jednym $\mathrm{z}$ ataków jest wypuszczenie trzech gołębi zrzucających bomby na wrogów.

\section{Wnioski}

Nikola Tesla lub jego wynalazki pojawiły się w ponad czterdziestu znalezionych przeze mnie tytułach, a jego postać występuje w dwunastu z nich. Choć do wiążących porównań potrzebne byłyby dane na temat częstotliwości występowania innych naukowców, można przypuszczać, że jest najczęściej pojawiającym się wynalazcą w grach cyfrowych.

Na podstawie powtarzalności cech w wymienionych kategoriach następujący obraz Tesli można uznać za ustabilizowany: jest ubranym w garnitur (91,6 proc. gier), wąsatym (75 proc.), szczupłym mężczyzną (10o proc. gier) i nieprzeciętnie inteligentnym wynalazcą (100 proc.). Przebywa w swoim laboratorium (58,3 proc.) w Colorado Springs (33,3 proc.), jest opanowany (50 proc.) i chętny do pomocy (33,3 proc.). Popada w konflikty, choć niemal wyłącznie z Thomasem Edisonem (konflikt między wynalazcami pojawia się w $75 \%$ badanych gier). Potrafi posługiwać się bronią (33,3 proc.) i kontrolować pioruny (33,3 proc.). Jego główne wynalazki to cewka Tesli (66,6 proc.), darmowa energia (33,3 proc.), wieża Wardenclyffe, teleport, komunikator, promień śmierci (każdy 25 proc.). Bywa postacią grywalną (58,3 proc.), stanowi główny temat produkcji (33,3 proc.), rozwiązuje problemy fabularne (33,3 proc.) lub jest reprezentantem grupy postaci historycznych (33,3 proc.).

Chociaż Nikola Tesla w grach cyfrowych jest postacią fantastyczną, trudno nie porównywać go z prawdziwą osobą wynalazcy. Konsekwentnie 
pojawiające się motywy $\mathrm{w}$ grach $\mathrm{z}$ jego udziałem są powiązane $\mathrm{z}$ danymi biograficznymi - jednak mimo to postać wydaje się stereotypowa. Rzuca się w oczy chociażby wąski zakres cech charakteru, które i tak w większości były trudne do określenia w badaniu, mimo że historyczny Tesla był bardzo barwną osobistością (długość odnośnej sekcji w artykule wynika raczej z konieczności opisowego uzasadnienia cech niż z ich liczby). Wątki biograficzne też pozostają ograniczone głównie do najbardziej popularnych elementów czy nawet powszechnych mitów na jego temat. W niektórych grach, zwłaszcza w tych, w których pomaga rozwiązać przeciwności napotykane przez gracza, stanowi bardziej archetyp wynalazcy niż przedstawienie prawdziwej osoby i z powodzeniem mógłby być zastąpiony fikcyjną postacią naukowca, bez żadnych nawiązań do samego Nikoli Tesli (TVL, DV, TO, IH).

Co może się wydawać zaskakujące, twórcy gier unikają tu tropu szalonego naukowca, do którego Tesla wydaje się predysponowany. Oprócz TGMT, która to gra najbardziej czerpie z biografii wynalazcy, oraz pojawiającego się czasem w innych grach zapracowania, Nikola Tesla wydaje się bardzo stonowaną, pozbawioną ekscentryczności postacią, bez jakichkolwiek dziwactw, które w dużej mierze charakteryzowały jego osobę w rzeczywistości.

Najbardziej zróżnicowaną kategorią, która definiuje Teslę, wydają się wynalazki. Jednak poza kontrolą elektryczności, cewką Tesli i Wieżą Wardenclyffe jego rzeczywiste wynalazki raczej nie są wspominane, a większość gier koncentruje się na wynalazkach fikcyjnych wymaganych dla fabuły i rozgrywki, jak np. wehikuł czasu, jetpack, bronie, teleport. Można przypuszczać, że obecność Tesli wynika raczej z chęci określenia genezy wymyślonych już wcześniej wynalazków.

Biorąc pod uwagę zróżnicowanie przedstawień Nikoli Tesli, można dojść do wniosku, że stanowią w mniejszym stopniu biograficzne czy edukacyjne odzwierciedlenie jego prawdziwej postaci, a w większym - popularną twarz dla archetypu genialnego naukowca (z wyjątkiem gier, które opierają się w całości na jego biografii). Użycie jego nazwiska sprawia wrażenie chwytu marketingowego wykorzystującego popularność tego wynalazcy w kulturze współczesnej. Co ciekawe, właściwie wszystkie gry zakładają u odbiorcy pewną znajomość osoby Tesli, co też wskazuje na wysoki stopień jego rozpoznawalności i utworzenie z niego pewnego symbolu geniuszu i nauki. 
Zważywszy jednak na rosnącą popularność Tesli w różnych tekstach kultury, widać że niezależnie od sposobu przedstawienia wizerunku genialny wynalazca rozpala wyobraźnię zarówno autorów, jak i odbiorców.

\section{Literatura}

Bartmiński, J. (2007). Językowe podstawy obrazu świata. Lublin: Wydawnictwo Uniwersytetu Marii Curie-Skłodowskiej.

Boniecki, A. (2004). Kulturowe i literackie konstrukcje wyrażania siebie i „,innych": wprowadzenie do imagologii. Prace Naukowe Akademii im. Jana Długosza w Częstochowie. Filologia Polska. Historia i Teoria Literatury, 14(1), 141-152.

Hall, S. (1997). The Work of Representation. W: S. Hall (red.), Representation. Cultural Representations and Signifying Practices (s.13-74), Londyn: Sage. Seifer, M.J. (1998). Wizard. The Life and Times of Nikola Tesla. Biography of a Genius. New York: Citadel Press.

Tołstoj, N.I. (1992). Język a kultura (niektóre zagadnienia słowiańskiej etnoligwistyki). Etnolingwistyka, tom 5, 15-25.

\section{Wykaz skrótów i ludografia}

TVL - 10tons Ltd (2018). Tesla vs Lovecraft [gra wieloplatformowa]. 10tons Ltd., Finlandia.

DV - Airtight Games (2010). Dark Void [PC]. Capcom, Japonia.

TBW - Archetype Global (2014). Tesla Breaks the World! [PC]. Archetype Global, USA.

SK - Cohen, O., Giacomo, F. (2016). Science Kombat [PC]. Superinterssante, Brazylia.

FGO - Delightworks (2015). Fate/Grand Order [Android, iOS]. Aniplex, Japonia.

ALT - Drandakis, H. (2017). Alternate [iOS]. Drandakis H., Grecja.

UWA - Origin Systems (1991). Ultima: Worlds of Adventure 2: Martian

Dreams [DOS]. Origin Systems, USA.

TO - Ready at Dawn (2015). The Order: 1886 [Playstation 4]. Sony Computer Entertainment, USA. 
TGMT - Redi Games (2017). The Great Mind of Tesla [Android, iOS]. Redi Games, Polska.

VSA - Studio spektar (2017). Viktor, a Steampunk Adventure [PC]. Studio spektar, Chorwacja.

IH - Tequila Works (2017). The Invisible Hours [gra wieloplatformowa]. Game Trust, USA.

TWM - Thoughtquake Studios (2011). Tesla: The Weather Man [PC]. Thoughtquake Studios, USA.

Data dostępu do źródeł internetowych wykorzystanych w tekście: 30 grudnia 2019 roku.

mgr Jagoda Kościelniak - doktorantka w Zakładzie Slawistyki i Studiów Bałkańskich Uniwersytetu Gdańskiego.

\section{Wizerunek Nikoli Tesli i jego wynalazków w grach cyfrowych}

Abstrakt: Artykuł ten przybliża sposób przedstawiania Nikoli Tesli w grach cyfrowych, w których serbsko-amerykański wynalazca zyskuje coraz większą popularność. W dwunastu tytułach, w których się pojawia, określone i opisane zostały następujące kategorie jego cech: wygląd, miejsce pobytu, osobowość, rola, umiejętności, wynalazki i relacje z innymi, które razem składają się na wizerunek genialnego inżyniera.

Stowa kluczowe: Nikola Tesla, szalony naukowiec, Thomas Edison, fizyka, znani naukowcy 
